\title{
EARLY ISOMETRIC EVERSION AND INVERSION CHANGES AFTER ACUTE ANKLE SPRAINS
}

\author{
Gediminas Tankevičius ${ }^{1}$, Donata Lankaitè ${ }^{1}$, \\ Aleksandras Kriščiūnas', Albertas Skurvydas ${ }^{2}$ \\ Lithuanian University of Health Sciences, Kaunas, Lithuania ${ }^{l}$ \\ Lithuanian Sports University, Kaunas, Lithuania ${ }^{2}$
}

\begin{abstract}
Research background and hypothesis. Most of the methods used to monitor ankle condition after acute ankle sprains do not provide knowledge about the functional state of the ankle, which is mostly dependent on muscles and proprioception. For this purpose we used isometric testing.

Research aim: to detect early isometric eversion and inversion peak torque changes after acute ankle sprains, and to compare them to the usual methods.

Research methods. The subjects were 80 athletes with acute grade II ankle sprain. All subjects were randomized into Isometric Testing Group (40 subjects), and Control Group (40 subjects). Both groups underwent the same rehabilitation programme. We measured isometric peak torque and peak torque differences between the healthy and injured legs in eversion and inversion movements of the ankle. The outcome measures were pain on activity, swelling, Lower Extremity Functional Scale score, isometric eversion and inversion strength, Square hop test, and Figure of Eight hop test.

Research results. There were no significant differences between parameters measured in both groups. Statistical analysis indicated significantly lower eversion and inversion strength of the injured limb, significant eversion and inversion deficit changes during the whole study. Pain on activity, and swelling changes were significant only on the first two weeks. Lower Extremity Functional Scale score changes were significant all three weeks. Eversion and inversion deficit correlated with Lower Extremity Functional Scale score.

Conclusion. Isometric testing detects early eversion and inversion changes and helps monitoring rehabilitation after acute lateral ankle sprains.
\end{abstract}

Keywords: peak torque, rehabilitation, monitoring.

\section{INTRODUCTION}

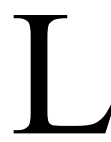

ateral ankle sprain is one of the most common injuries in sports (about $15 \%$ of all sports traumas), and various recreational activities (Hubbard et al., 2008). About ten per 1000 people per year suffer from this pathology (Bleakley et al., 2010; Rogier et al., 2008). Ankle sprains result in loss of playing or working time as well as in medical expenditure (Fong et al., 2009), about a quarter of injured people are unable to participate in social activities for more than seven days. Without adequate treatment and rehabilitation ankle sprains may lead to various complications including re-sprains, chronic ankle instability, persistent swelling or even arthrosis (Anandacoomarsamy, Barnsley, 2005; Struijs, Kerkhoff, 2010).

In acute phase ankle sprains are associated with pain, swelling, loss of function, and/or instability, there is also a decrease in ankle evertor and invertor muscle strength due to neuromuscular regulation impairment (Richie, 2001).

There have been studies published which monitored pain, swelling, and self-reported function after acute ankle sprains (Mawdsley et 
al., 2000; Bleakley et al., 2007; Rogier et al., 2008; Bleakley et al., 2010). The problem is that most of these methods are quite subjective; they do not provide knowledge about the functional state of the ankle, which is mostly dependent on muscles and proprioception (Richie et al., 2001). We suggest monitoring early eversion and inversion changes after acute ankle sprains, and by doing that to prevent further complications, such as chronic or functional ankle instability. A few studies, that used ankle eversion and inversion measurement, focused on symptom-free patients or patients with residual problems like chronic ankle instability. This basically means dealing already with ankle sprain complications (Willems et al., 2002; Arnold et al., 2009). These studies used isokinetic testing.

In order to measure ankle eversion and inversion strength after acute ankle sprains, when there is a swelling and a significant loss of range of motion and function, isokinetic testing would not be recommended because eversion and inversion movements would be painful, and they would put an additional stress to the already injured ligaments. In these cases isometric testing can be helpful - the tested leg is immobilized by several straps, there is no movement during testing, and therefore the injured ligaments are not stressed.

A few studies used isometric ankle testing (Kaminski et al., 1999; Webber, Porter, 2010; Smith et al., 2012), but they were investigating patients with residual problems like functional ankle instability. E. Holme et al. (1999) performed isometric ankle strength measurement six weeks post ankle injury. There was one study in which isometric testing (eccentric-isometric) was used three weeks following acute ankle sprain (Konradsen et al., 1998). We have not found any data published about isometric testing during the acute phase after ankle sprains. We think isometric ankle eversion and inversion strength measurement would be a very helpful tool to determine the extent of functional impairment after acute ankle sprains. It would be useful in monitoring the whole rehabilitation process - knowing whether eversion or inversion (or both) is mostly affected enables us to adjust rehabilitation programme for each patient individually, and thus to ensure the progress.

The aim of this study was to detect early eversion and inversion changes after acute ankle sprains, and to compare them to the usual methods.

\section{RESEARCH METHODS}

Subjects. During the period between August, 2011 to August, 2012, 139 athletes with ankle trauma were evaluated for eligibility. They filled in a questionnaire involving questions about previous ankle traumas and athlete's training intensity. They also had to fill in the Lower Extremity Functional Score questionnaire. Clinical measurements were performed by the doctors. In total 80 athletes (53 males, mean age $25.29 \pm 4.46$ years, mean height $182.72 \pm 5.58 \mathrm{~cm}$, mean weight $82.5 \pm 4.6 \mathrm{~kg}$, and 27 females, mean age $26.03 \pm 4.61$ years, mean height $170.93 \pm 6.24 \mathrm{~cm}$, mean weight $61.87 \pm 5.12 \mathrm{~kg}$ ) met inclusion criteria and were included in the trial. The sample size was limited by our capabilities to enrol more patients during this period. Before injury all subjects had been exercising at least three times per week for the last year, each exercising session lasting at least one hour. Inclusion criteria were: recent (up to five days) grade II ankle sprain, no tendon ruptures, no detected bone fractures, no ankle trauma (of either leg) within the last year. The differentiation between ankle sprain grades was based on pain, swelling, mechanical stability (anterior drawer test and talar tilt test) and ability to bear weight (fully or partially) on the injured leg.

All subjects signed Informed Patient Consent Form, and were randomly assigned to two groups Isometric Testing Group (40 subjects, mean age $26.55 \pm 5.15$ years, mean height $178.1 \pm 8.15 \mathrm{~cm}$, mean weight $73.43 \pm 11.02 \mathrm{~kg}$ ), and Control Group (40 subjects, age $24.63 \pm 3.57$ years, height $177.93 \pm 7.34 \mathrm{~cm}$, weight $75.08 \pm 11.25 \mathrm{~kg}$ ).

Rehabilitation protocol. All patients in both groups underwent the same rehabilitation programme- functional AIRCAST (Air-stirrup) type ankle brace, home based exercise programme, and cryotherapy. We preferred not to use nonsteroidal anti-inflammatory drugs because of their healing reducing effect. They were prescribed only in order to prevent secondary damage in cases of intense inflammation, and used only up to five days (Mehallo et al., 2006).

Functional ankle brace was chosen in order to protect ankle from eversion and inversion movements (to protect the injured ligaments), but to allow mobility (Kerkhoffs et al., 2002; Beynnon et al., 2006; Lin et al., 2010). Each subject was shown how the brace should be put on, and they could try putting the brace on themselves, to make 
sure the brace would be worn properly. It was recommended to wear the brace during weight bearing (walking, going out).

Home based exercise programme included stretching exercises, proprioception training, muscle strength and endurance exercises (Petersen et al., 2013). On baseline home based programme included mild stretching exercises, performed with no pain (mainly to maintain ankle dorsiflexion), and proprioception exercises - standing on even surface three-four sets of one minute on each leg with as little support as possible, four-five times per day. Every week the programme was gradually complemented with proprioception exercises using elastic bands, proprioception exercises on soft even surface, and progressing stretching, muscle strength and endurance exercises. Each subject was shown how to do all exercises, and also received written instructions.

After exercising, cryotherapy was recommended because of its pain, swelling, and inflammation reducing effect (Bleakley et al., 2007; Petersen et al., 2013), all subjects received a verbal explanation on proper ice application - ice cubes mixed with water, and applied for 15-20 minutes threefour times per day (maintaining at least three hour intervals between each application). It was recommended to keep the injured limb elevated while applying cold.

Isometric testing. We have introduced monitoring of eversion and inversion during rehabilitation, this being an objective way to evaluate the functional state of the ankle. Isometric mode was chosen for testing because of its safety no movement allows to measure muscle strength without posing any tension to the injured ligaments; therefore the testing is possible in early stages of rehabilitation process.

We used a Biodex System 4 Pro Dynamometer and Biodex Advantage Software Package (Biodex Medical Systems Inc, Shirley, NY) to determine isometric peak torque and peak torque differences between the healthy and injured legs in eversioninversion movements of the ankle. Subjects were tested in a semi recumbent position. In order to minimize substitution from other muscles the knee was in extension, and to avoid additional movements two straps-one proximal to the knee and one around the hips-were wrapped, patients were asked to rest their arms on their chest. Subjects wore their own flat shoes during testing; each shoe was tightly fastened with 2 straps to the dynamometer footplate to minimize movement between the shoe sole and the footplate surface (Figure 1).

Protocol. Before testing, each subject had to perform a five minute warm up on a stationary bicycle with low resistance (50 watts) at average speed (60-70 rpm). After five minutes of warm up, the patient was positioned on the dynamometer chair, the first tested leg being the healthy one. Each subject could see the screen with torque curve, and was given a verbal explanation on how to carefully and gradually increase effort to reach a visible torque curve plateau on the screen. With this biofeedback every subject performed three warm-up eversion and inversion repetitions, and

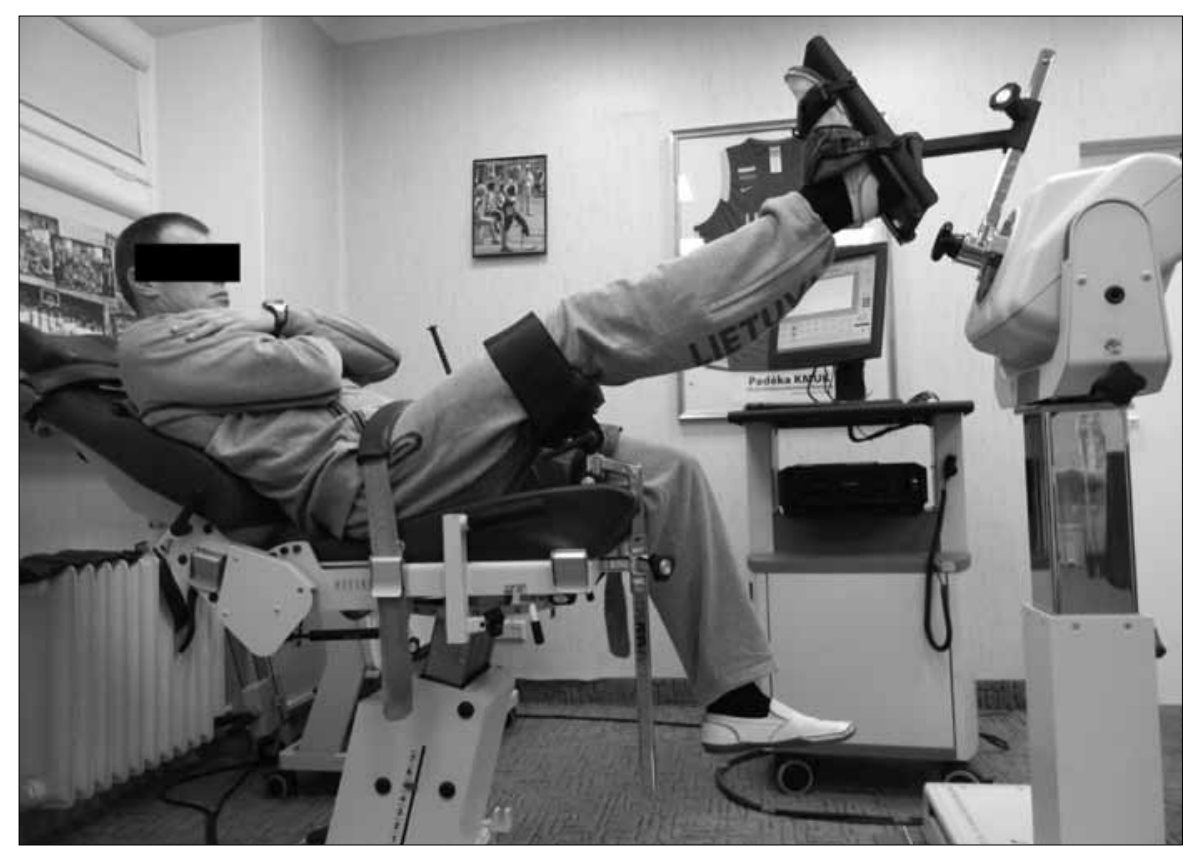

Figure 1. Patient positioning during testing 
three submaximal repetitions with ten seconds rest period in between.

We used our own created testing protocol. The test consisted of three maximal repetitions of isometric eversion and inversion at seven degrees of ankle inversion. The dynamometer footplate position of seven degrees of inversion was chosen because in the natural ankle range of motion inversion is greater than eversion, and measuring at this angle best represents both eversion and inversion (Tankevicius et al., 2013). In order to reach a visible eversion and inversion torque curve plateau ten seconds were given. Between every repetition ten second rest period was given. Peak torque was determined by calculating the average peak torque of all three repetitions. All subjects received consistent verbal encouragement. The difference of eversion and inversion peak torques between both legs was chosen as the main outcome measure.

Outcome Measures. The outcome measures for both Control group and Isometric Testing group were pain on activity (while standing on the injured leg); swelling, measured in the "figure of eight" method; Lower Extremity Functional Scale (LEFS) score; Figure of Eight hop test, and Square hop test. Additionally, Isometric Testing group underwent isometric eversion and inversion muscle strength measurement every week.

- Pain was assessed using Visual Analogue Scale (VAS). All subjects were asked to stand on the injured leg for one minute, trying to use as little support as possible. After one minute they were asked to draw a vertical line on a horizontal scale to indicate a point that corresponded to the intensity of the pain while standing on the injured leg. The length from the left end to the vertical mark made by the patient was measured in millimetres (Phan et al., 2011).

- Ankle circumference was measured on both legs using the "figure of eight" method, which is a reliable tool to measure ankle swelling (Rohner-Spengler et al., 2007). Swelling was defined as the difference of circumference between the unaffected and the injured legs.

- Lower Extremity Functional Scale (LEFS) is a self-completed questionnaire containing 20 questions about severity of symptoms, the maximum score being 80 (Binkley et al., 1999).

- Isometric ankle eversion and inversion testing. The difference of eversion and inversion peak torques between both legs (deficit) was chosen as the main outcome measure.

- In order to evaluate functional performance, and to compare the results between the groups, two hop tests were carried out on the last visit- Figure of Eight, and Square hop tests (Sharma et al., 2011). For the Figure of Eight hop test all subjects were asked to hop on one leg around two cones placed five meters apart as fast as possible.

- For the Square hop test, a square of dimensions 40 x 40 centimetres was marked on the floor with tape, and all subjects were instructed to hop in and out of the square moving in a circle for five times. Before hop tests, all subjects warmed up on a stationary bicycle for five minutes with small resistance. Then each of them received an explanation of the tests, and had five minutes to familiarize with performance. After that all subjects were asked to perform each test three times on each leg, average of two best times was chosen as outcome measure. Each subject was given one minute relaxation time after every test.

Since isometric testing have been used for the first time in acute stages after ankle sprains all these outcome measures were also used in order to assess isometric testing safety. Pain, swelling, functional scale score, isometric testing results on the third week, and hop tests results were compared between the two groups to see whether isometric testing, used in early days after acute ankle sprain, had caused any alteration in these measures during rehabilitation.

Study Protocol. All subjects were asked to come four times in total: the first visit (baseline) was from three to five days after acute ankle sprain. Another three visits were performed respectively every week. The exact schedule and outcome measures taken on each visit are shown in Table 1.

Data analysis. Descriptive data are presented as means and standard deviation (SD). Statistical Package for the Social Sciences (SPSS) for Windows (version 17.0) was used for statistical analysis. Paired t-test was used to determine statistically significant differences within each group, Independent Sample t-test was used to determine statistically significant differences between the two groups, $\mathrm{p}<0.05$ was considered statistically significant. Reliability of hop tests was assessed using intraclass correlation coefficient (ICC 2, 1), and Standard Error of Measurement (SEM). 


\begin{tabular}{|c|c|c|c|c|}
\hline Outcome measures & Baseline & Week 1 & Week 2 & Week 3 \\
\hline \multicolumn{5}{|c|}{ Isometric Testing Group } \\
\hline Pain with activity & + & + & + & + \\
\hline Swelling & + & + & + & + \\
\hline Lower Extremity Functional Scale & + & + & + & + \\
\hline Isometric testing & + & + & + & + \\
\hline Figure of Eight, and Square Hop tests & - & - & - & + \\
\hline \multicolumn{5}{|c|}{ Control Group } \\
\hline Pain with activity & + & + & + & + \\
\hline Swelling & + & + & + & + \\
\hline Lower Extremity Functional Scale & + & + & + & + \\
\hline Isometric testing & - & - & - & + \\
\hline Figure of Eight, and Square Hop & - & - & - & + \\
\hline
\end{tabular}

Table 1. Visit schedule and outcome measures taken on each visit

\section{RESEARCH RESULTS}

Statistical analysis showed no differences between Isometric Testing and Control group age, height and weight. The summary of the main outcome measures in both groups is shown in Table 2.

Pain with activity gradually decreased throughout the rehabilitation period in both groups, however statistically significant changes in pain intensity were only found on the 1 st $(\mathrm{p}<0.01)$ and 2 nd $(p=0.04)$ week after ankle trauma. No significant changes were detected between the results of Isometric Testing and Control groups $(\mathrm{p}>0.05)$.

Ankle circumference of the affected limb gradually returned to normal in both groups. The changes of swelling were statistically significant on the first two weeks $(p<0.01)$. The swelling did not differ between Isometric testing and Control groups $(\mathrm{p}>0.05)$.

The Lower Extremity Functional Scale (LEFS) scores from baseline till Week 3 gradually increased, each week the increase being statistically significant $(\mathrm{p}<0.01)$. There were no statistically significant differences between Isometric Testing and Control groups ( $\mathrm{p}>0.05)$.

Isometric muscle testing in Isometric Testing group on baseline showed eversion and inversion deficits - eversion and inversion strength of the injured limb was significantly lower, $\mathrm{p}<0.01$. Muscle strength deficits gradually decreased during rehabilitation period and within three weeks returned to normal (eversion and inversion differences between both legs normally can be up to $10 \%$ ), each week the changes were statistically significant, $\mathrm{p}<0.01$ (Figure 2).

On Week 3, patients of Control Group underwent isometric ankle eversion and inversion testing. Compared to the results of Isometric Testing group, no statistically significant differences were detected $(\mathrm{p}>0.05)$.

In order to make sure hop tests are safe for each patient, we relied on isometric testing results. Only those subjects, whose eversion and inversion strength deficit did not exceed $15 \%$, were allowed to perform hop tests because strength deficit of $15 \%$ or less indicated sufficient eversion and inversion support for the injured ankle (normally there is no muscle imbalance between the two limbs (Lin et al., 2009). Eight people from the Isometric Testing group, and ten people from the Control group were excluded from hop tests because of this reason.

Hop tests results showed moderate to high intraclass correlation coefficients (ICC 2, 1), shown in Table 3, no statistically significant differences between the groups were observed ( $p>0.05$ ).

Eversion deficit correlated with the Lower Extremity Functional Scale scores on Baseline, Week1, and Week 2, correlation $(-0.50)-(-0.33)$, $\mathrm{p}<0.05$, inversion deficit correlated with the Lower Extremity Functional Scale score on Baseline and Week1, correlation $(-0.63)-(-0.52), \mathrm{p}<0.05$. 
Table 2. Summary of the main outcome measures in both groups, all data presented as means \pm standard deviation

\begin{tabular}{|c|c|c|c|c|}
\hline \multirow{2}{*}{$\begin{array}{c}\text { The main outcome measures } \\
\text { Outcome Measures }\end{array}$} & \multicolumn{4}{|c|}{ Isometric Testing Group } \\
\hline & Baseline & Week 1 & Week 2 & Week 3 \\
\hline $\begin{array}{l}\text { Pain with activity, VAS: } \\
\text { Isometric Testing Group } \\
\text { Control Group }\end{array}$ & $\begin{array}{l}3.99 \pm 1.02 \\
3.94 \pm 0.80\end{array}$ & $\begin{array}{l}2.60 \pm 0.60 \\
2.59 \pm 0.51\end{array}$ & $\begin{array}{l}2.41 \pm 0.46 \\
2.40 \pm 0.58\end{array}$ & $\begin{array}{l}2.31 \pm 0.54 \\
2.32 \pm 0.58\end{array}$ \\
\hline $\begin{array}{l}\text { Swelling, cm: } \\
\text { Isometric Testing Group } \\
\text { Control Group }\end{array}$ & $\begin{array}{l}1.98 \pm 0.65 \\
1.97 \pm 0.38\end{array}$ & $\begin{array}{l}1.18 \pm 0.56 \\
1.16 \pm 0.30\end{array}$ & $\begin{array}{l}0.76 \pm 0.53 \\
0.74 \pm 0.36\end{array}$ & $\begin{array}{l}0.64 \pm 0.43 \\
0.70 \pm 0.38\end{array}$ \\
\hline $\begin{array}{l}\text { LEFS: } \\
\text { Isometric Testing Group } \\
\text { Control Group }\end{array}$ & $\begin{array}{l}23.55 \pm 3.70 \\
24.33 \pm 6.91\end{array}$ & $\begin{array}{l}40.15 \pm 9.97 \\
40.25 \pm 7.04\end{array}$ & $\begin{array}{l}57.13 \pm 7.51 \\
55.50 \pm 6.24\end{array}$ & $\begin{array}{l}72.50 \pm 5.12 \\
70.48 \pm 4.59\end{array}$ \\
\hline $\begin{array}{l}\text { Eversion Peak Torque, Healthy Leg, Nm: } \\
\text { Isometric Testing Group } \\
\text { Control Group }\end{array}$ & $\begin{array}{c}29.04 \pm 7.13 \\
- \\
\end{array}$ & $\begin{array}{c}29.10 \pm 7.39 \\
-\end{array}$ & $\begin{array}{c}29.05 \pm 7.26 \\
-\end{array}$ & $\begin{array}{l}29.08 \pm 7.35 \\
27.21 \pm 6.09 \\
\end{array}$ \\
\hline $\begin{array}{l}\text { Eversion Peak Torque, Injured Leg, Nm: } \\
\text { Isometric Testing Group } \\
\text { Control Group }\end{array}$ & $\begin{array}{c}18.38 \pm 4.73 \\
-\end{array}$ & $\begin{array}{c}21.64 \pm 4.73 \\
-\end{array}$ & $\begin{array}{c}24.73 \pm 5.79 \\
-\end{array}$ & $\begin{array}{l}27.01 \pm 6.70 \\
24.54 \pm 5.57\end{array}$ \\
\hline $\begin{array}{l}\text { Inversion Peak Torque, Healthy Leg, Nm: } \\
\text { Isometric Testing Group } \\
\text { Control Group }\end{array}$ & $\begin{array}{c}30.25 \pm 7.37 \\
-\end{array}$ & $\begin{array}{c}30.53 \pm 7.76 \\
-\end{array}$ & $\begin{array}{c}30.83 \pm 7.27 \\
-\end{array}$ & $\begin{array}{l}30.90 \pm 7.56 \\
29.13 \pm 5.91\end{array}$ \\
\hline $\begin{array}{l}\text { Inversion Peak Torque, Injured Leg, Nm: } \\
\text { Isometric Testing Group } \\
\text { Control Group }\end{array}$ & $\begin{array}{c}20.31 \pm 5.29 \\
-\end{array}$ & $\begin{array}{c}23.98 \pm 6.25 \\
-\end{array}$ & $\begin{array}{c}26.82 \pm 6.67 \\
-\end{array}$ & $\begin{array}{l}28.85 \pm 7.42 \\
26.90 \pm 5.50\end{array}$ \\
\hline $\begin{array}{l}\text { Square Hop Test, Healthy Leg, s: } \\
\text { Isometric Testing Group } \\
\text { Control Group }\end{array}$ & $\begin{array}{l}- \\
-\end{array}$ & $\begin{array}{l}- \\
-\end{array}$ & $\begin{array}{l}- \\
- \\
-\end{array}$ & $\begin{array}{l}14.57 \pm 2.05 \\
14.73 \pm 1.99\end{array}$ \\
\hline $\begin{array}{l}\text { Square Hop Test, } \\
\text { Injured Leg, s: } \\
\text { Isometric Testing Group } \\
\text { Control Group }\end{array}$ & $\begin{array}{l}- \\
-\end{array}$ & $\begin{array}{l}- \\
-\end{array}$ & $\begin{array}{l}- \\
- \\
-\end{array}$ & $\begin{array}{l}15.90 \pm 2.48 \\
15.99 \pm 2.42\end{array}$ \\
\hline $\begin{array}{l}\text { Figure of Eight Hop test, } \\
\text { Healthy Leg, s: } \\
\text { Isometric Testing Group } \\
\text { Control Group }\end{array}$ & $\begin{array}{l}- \\
-\end{array}$ & $\begin{array}{l}- \\
-\end{array}$ & $\begin{array}{l}- \\
- \\
\end{array}$ & $\begin{array}{l}7.11 \pm 0.61 \\
7.13 \pm 0.55\end{array}$ \\
\hline $\begin{array}{l}\text { Figure of Eight Hop test, } \\
\text { Injured Leg, s: } \\
\text { Isometric Testing Group } \\
\text { Control Group }\end{array}$ & $\begin{array}{l}- \\
-\end{array}$ & $\begin{array}{l}- \\
-\end{array}$ & - & $\begin{array}{l}7.66 \pm 0.63 \\
7.71 \pm 0.67\end{array}$ \\
\hline
\end{tabular}

Figure 2. Changes of eversion and inversion deficit during rehabilitation

Note. \# - statistically reliable eversion changes $(\mathrm{p}<0.05)$; * - statistically reliable inversion changes $(\mathrm{p}<0.05)$.

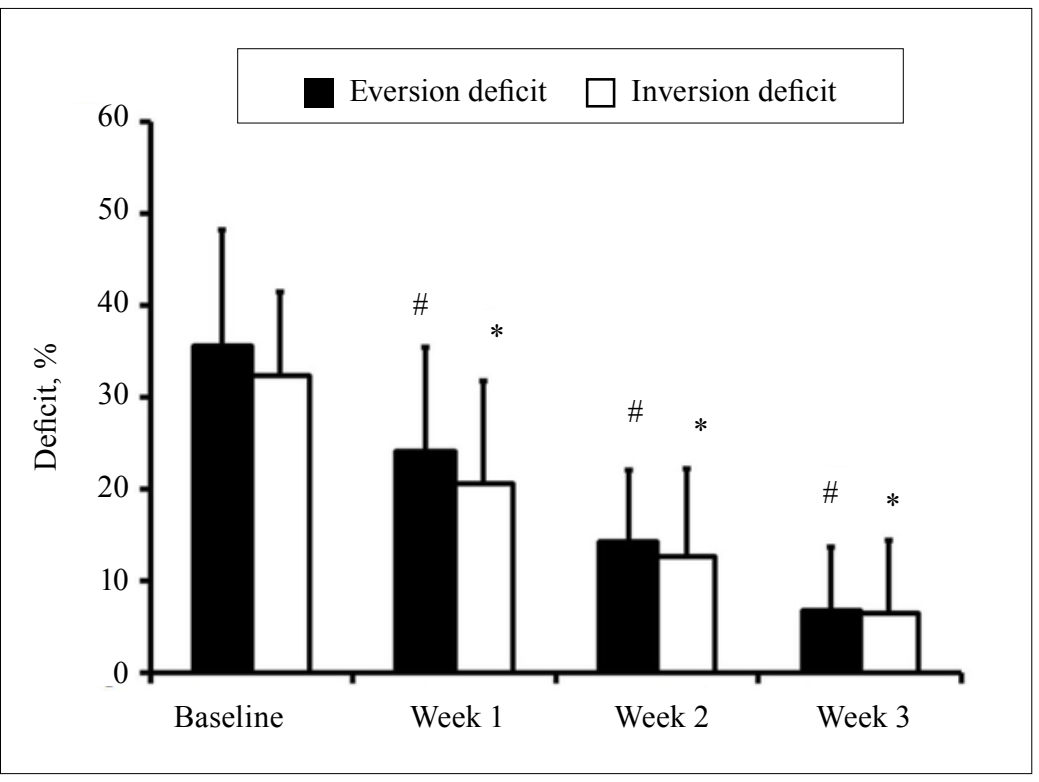




\begin{tabular}{|l|c|c|c|c|}
\hline \multirow{2}{*}{\multicolumn{1}{|c|}{ Reliability }} & \multicolumn{2}{|c|}{ Square Hop Test } & \multicolumn{2}{c|}{ Figure of Eight Hop Test } \\
\cline { 2 - 5 } & Healthy Leg & Injured Leg & Healthy Leg & Injured Leg \\
\hline ICC & & & & \\
(95\% confidence interval): & & & & \\
Isometric Testing Group & 0.857 & 0.889 & 0.889 & 0.651 \\
& $(0.727-0.927)$ & $(0.786-0.944)$ & $(0.786-0.944)$ & $(0.399-0.813)$ \\
Control Group & 0.962 & 0.949 & 0.777 & 0.759 \\
& $(0.912-0.983)$ & $(0.894-0.976)$ & $(0.581-0.887)$ & $(0.554-0.878)$ \\
\hline Standard Error of & & & & \\
Measurement (SEM): & 0.77 & 0.83 & 0.19 & 0.37 \\
Isometric Testing Group & 0.39 & 0.55 & 0.26 & 0.33 \\
Control Group & & & & \\
\hline
\end{tabular}

Table 3. Hop test reliability

\section{DISCUSSION}

Even though ankle sprains may recover within a relatively short period, A. B. Aiken et al. published a study where they concluded that one month after ankle sprain clinical findings suggested full recovery, however laboratory measures (active and passive mobility, plantarflexion and dorsiflexion tests,) detected residual deficits (Aiken et al., 2008). Results of our study match with such data - clinical findings, such as swelling, and pain subsided during the first two weeks. However isometric testing showed significant changes during all three weeks.

Safety. Our main findings show that isometric testing can be safely applied in early stages of ankle sprains - all measured parameters (pain, swelling, LEFS score, hop tests) did not differ between the two groups. No harmful effects were noticed, the improvement was the same in both groups.

Eversion and inversion deficit. Results of our study show there is a significant loss of eversion and inversion strength in the injured limb after acute ankle sprains. On baseline, eversion is about $36 \%$, and inversion is about $32 \%$ smaller in the injured limb than it is in the healthy one. This is most probably caused by soft tissue damage, hematoma, local inflammation, and neuromuscular impairment. When measured every week after the injury, this strength deficit gradually decreased, representing improvement of functional state of the ankle. In our practice we noticed that in such cases when the deficit remains the same or increases, it might be a hint of more severe pathology or a complicated course. Such patients should be treated with more cautions and additional diagnostic tests (MRI, ultrasound, etc.) should be considered. In our study the 18 subjects, whose isometric testing results on Week 3 testing showed greater than $15 \%$ deficit, were referred to more detailed diagnosing and additional pathology (bone oedema, osteochondral lesions, syndesmotic injury, peroneal tendon retinaculum injury, etc.) was diagnosed for seven patients. Further research is needed to investigate isometric testing results connection with MRI findings.

Isometric testing advantages. We found that another reliable tool was Lower Extremity Functional Scale, its score changes being statistically significant every week. However, Lower Extremity Functional Scale result only represents a self-reported function, and it is not specific. Isometric testing shows how much eversion or inversion (or both) is affected. Thus it is possible to approach each patient very individually, basing the progress of rehabilitation programme on the results of isometric muscle testing.

Sufficient eversion and inversion strength ensures functional stability of injured ankle. It provides objective reason to allow patients to gradually increase intensity and complexity of exercises. We chose it as a criterion for allowing patients to perform hop tests. Isometric testing can be a helpful tool for accelerating and personalizing athlete rehabilitation. For example, in our study we noticed that some patients in Isometric Testing group had eversion and inversion deficit smaller than $15 \%$ even in first weeks after injury (4 patients on Week I, 13 patients on Week II). We think their rehabilitation program could have been accelerated, and recovery time shortened by approaching them individually. Further research is planned for setting guidelines based on isometric testing results.

Biofeedback. During testing each patient can see their results, which help them better understand their situation, and validity of their rehabilitation. Obtained objective data motivate the patient, and they feel closely involved in the whole rehabilitation process. 
Availability. Many sports centres in the world have dynamometers and could use them for isometric eversion and inversion testing. We are introducing this method as a safe and objective tool to be used together with the usual ones. Testing data should be assessed taking into consideration all other ankle function parameters.

Limitations. We focused on safety and implementation issues in order to introduce this method. Our study was performed in a limited period of time and further research should include longterm follow up, more detailed eversion and inversion deficit analysis, search for correlations between deficits and recovery time. We would like to further investigate the relationship between isometric testing results and possible underlying pathology (functional reflection of organic pathology).

\section{CONCLUSIONS AND PERSPECTIVES}

Isometric testing detects early eversion and inversion changes. We suggest that isometric eversion and inversion testing is safe and helpful in monitoring rehabilitation after acute lateral ankle sprains. It provides more information about the functional state of the injured ankle, and enables the physician to better understand the extent of the injury. Isometric testing helps to closely followup the rehabilitation progress, and it has positive biofeedback. We have also noticed that isometric testing is a very useful tool in individualising rehabilitation programs.

\section{REFERENCES}

Aiken, A. B., Pelland, L., Brison, R. et al. (2008). Shortterm natural recovery of ankle sprains following discharge from emergency departments. Journal of Orthopaedic \& Sports Physical Therapy, 38 (9), 566-571.

Anandacoomarasamy, A., Barnsley, L. (2005). Long term outcomes of inversion ankle injuries. British Journal of Sports Medicine, 39 (3), e 14.

Arnold, B. L., Linens, S. W., de la Motte, S. J. et al. (2009). Concentric Evertor Strength Differences and Functional Ankle Instability: A Meta-Analysis. Journal of Athletic Training, 44 (6), 653-662.

Beynnon, B. D., Renström, P. A., Haugh, L. et al. (2006). A prospective, randomized clinical investigation of the treatment of first-time ankle sprains. American Journal of Sports Medicine, 34 (9), 1401-1412.

Binkley, J. M., Stratford, P. W., Lott, S. A. et al. (1999). The Lower Extremity Functional Scale (LEFS): Scale development, measurement properties, and clinical application. Physical Therapy, 79 (4), 371-383.

Bleakley, C. M., O’Connor, S. R., Tully, M. A. et al. (2010). Effect of accelerated rehabilitation on function after ankle sprain: Randomised controlled trial. British Medical Journal, 340, c 1964.

Bleakley, C. M., O’Connor, S., Tully, M. A. et al. (2007). The PRICE study (Protection Rest Ice Compression Elevation): Design of a randomised controlled trial comparing standard versus cryokinetic ice applications in the management of acute ankle sprain. $B M C$ Musculoskeletal Disorders, 19 (8), 125.

Fong, D. T., Chan, Y. Y., Mok, K. M. et al. (2009). Understanding acute ankle ligamentous sprain injury in sports. Sports Medicine, Arthroscopy, Rehabilitation, Therapy \& Technology, 30 (1), 14.

Holme, E., Magnusson, S. P., Becher, K. et al. (1999). The effect of supervised rehabilitation on strength, postural sway, position sense and re-injury risk after acute ankle ligament sprain. Scandinavian Journal of Medicine \& Science in Sports, 9 (2), 104-109.
Hubbard, T. J., Hicks-Little, C. A. (2008). Ankle ligament healing after an acute ankle sprain: An evidence-based approach. Journal of Athletic Training, 43 (5), 523-529.

Kaminski, T. W., Perrin, D. H., Gansneder, B. M. (1999). Eversion strength analysis of uninjured and functionally unstable ankles. Journal of Athletic Training, 34 (3), 239-245.

Kerkhoffs, G. M., Struijs, P. A., Marti, R. K. et al. (2002). Different functional treatment strategies for acute lateral ankle ligament injuries in adults. Cochrane Database of Systematic Reviews, (3), CD002938.

Konradsen, L., Olesen, S., Hansen, H. M. (1998). Ankle sensorimotor control and eversion strength after acute ankle inversion injuries. American Journal of Sports Medicine, 26 (1), 72-77.

Lin, C. W., Hiller, C. E., de Bie, R. A. (2010). Evidencebased treatment for ankle injuries: A clinical perspective. Journal of Manual \& Manipulative Therapy, 18 (1), 22-28.

Lin, W. H., Liu, Y. F., Hsieh, C. C. et al. (2009). Ankle eversion to inversion strength ratio and static balance control in the dominant and non-dominant limbs of young adults. Journal of Science and Medicine in Sport, 12 (1), 42-49.

Mawdsley, R. H., Hoy, D. K., Erwin, P. M. (2000). Criterion-related validity of the figure-of-eight method of measuring ankle edema. Journal of Orthopaedic \& Sports Physical Therapy, 30 (3), 149-153.

Mehallo, C. J., Drezner, J. A., Bytomski, J. R. (2006). Practical management: Nonsteroidal anti-inflammatory drug (NSAID) use in athletic injuries. Clinical Journal of Sports Medicine, 16 (2), 170-174.

Petersen, W., Rembitzki, I. V., Koppenburg, A. G. et al. (2013). Best R. Treatment of acute ankle ligament injuries: A systematic review. Archives of Orthopaedic and Trauma Surgery, 133 (8), 1129-1141.

Phan, N. Q., Blome, C., Fritz, F. et al. (2011). Assessment of pruritus intensity: Prospective study on validity and 
reliability of the Visual Analogue Scale, Numerical Rating Scale and Verbal Rating Scale in 471 patients with chronic pruritus. Acta Dermato Venereologica, 92, 502-507.

Richie, D. H. Jr. (2001). Functional instability of the ankle and the role of neuromuscular control: A comprehensive review. Journal of Foot and Ankle Surgery, 40 (4), 240-251.

Rogier, M., van Rijn, R. M., van Os, A. G. et al. (2008). What is the clinical course of acute ankle sprains? A systematic literature review. American Journal of Medicine, 121 (4), 324-331.

Rohner-Spengler, M., Mannion, A. F., Babst, R. (2007). Reliability and minimal detectable change for the figureof-eight-20 method of, measurement of ankle edema. Journal of Orthopaedic and Sports Physical Therapy, 37 (4), 199-205.

Sharma, N., Sharma, A., Singh Sandhu, J. (2011). Functional performance testing in athletes with functional ankle instability. Asian Journal of Sports Medicine, 2 (4), 249-258.
Smith, B. I., Docherty, C. L., Simon, J. et al. (2012). Ankle strength and force sense after a progressive, 6-week strength-training program in people with functional ankle instability. Journal of Athletic Training, 47 (3), 282-288.

Struijs, P. A., Kerkhoffs, G. M. (2010). Ankle sprain. Clinical Evidence (Online), May 13, pii: 1115.

Tankevicius, G., Lankaite, D., Krisciunas, A. (2013). Test-Retest Reliability of Biodex System 4 Pro for Isometric Ankle Eversion and Inversion Measurement. Journal of Sport Rehabilitation, 22, 212-215.

Webber, S. C., Porter, M. M. (2010). Reliability of ankle isometric, isotonic, and isokinetic strength and power testing in older women. Physical Therapy, 90 (8), 11651175.

Willems, T., Witvrouw, E., Verstuyft, J. et al. (2002). Proprioception and muscle strength in subjects with a history of ankle sprains and chronic instability. Journal of Athletic Training, 37 (4), 487-493.

\title{
ANKSTYVIEJI IZOMETRINĖS EVERSIJOS IR INVERSIJOS JĖGOS POKYČIAI PO ŪMIŲ ČIURNOS RAIŠČIŲ TRAUMU
}

\author{
Gediminas Tankevičius ${ }^{1}$, Donata Lankaitè ${ }^{1}$, \\ Aleksandras Kriščiūnas ${ }^{1}$, Albertas Skurvydas ${ }^{2}$ \\ Lietuvos sveikatos mokslu universitetas ${ }^{1}$, Kaunas, Lietuva \\ Lietuvos sporto universitetas ${ }^{2}$, Kaunas, Lietuva
}

\section{SANTRAUKA}

Tyrimo pagrindimas ir hipotezé. Dauguma metodų, naudojamų stebėti čiurną po ūmių raiščių traumų, nesuteikia pakankamai duomenų apie funkcinę čiurnos būklę, kuri labiausiai priklauso nuo raumenu funkcijos ir propriorecepcijos. Šiuo tikslu pritaikėme izometrinį testavimą.

Tikslas - išmatuoti ankstyvus izometrinès eversijos bei inversijos jègos pokyčius po ūmiu čiurnos raiščių traumų ir palyginti juos su ịprastai naudojamų metodų rodiklių pokyčiais.

Metodai. Buvo tirta 80 sportininkų, patyrusių ūmią II laipsnio čiurnos raiščių traumą. Visi tiriamieji suskirstyti i dvi grupes: izometrinio testavimo grupe (40 tiriamujų) ir kontrolinę (40 tiriamujų). Abi grupès turèjo vienodą reabilitacijos programą. Matuota sveikos bei pažeistos kojos izometrinès eversijos bei inversijos jèga ir šios jègos skirtumai. Buvo nustatomas čiurnos skausmas apkrovos metu, čiurnos patinimas, kojos funkcija įvertinta skalès balais, fiksuoti kvadrato ir aštuoneto formos šuolių testų rezultatai.

Rezultatai. Tyrimo rodikliai tarp grupių statistiškai nesiskyrè. Statistinè analizė atskleidè patikimai mažesnę pažeistos kojos eversijos bei inversijos jègą, patikimus šios jègos deficito pokyčius viso tyrimo metu. Čiurnos skausmo apkrovos metu ir patinimo pokyčiai buvo statistiškai patikimi tik pirmąsias dvi savaites. Kojos funkcinès skalès balai kito statistiškai patikimai viso tyrimo metu. Eversijos bei inversijos jègos deficitas koreliavo su kojos funkcinès skalès balais.

Aptarimas ir išvados. Izometriniu matavimo būdu galima aptikti ankstyvus eversijos bei inversijos jègos pokyčius po ūmių čiurnos raiščių traumų. Tai leidžia visapusiškiau stebèti reabilitacijos eigą.

Raktažodžiai: jègos momentas, reabilitacija, stebėsena.

Gauta 2013 m. spalio $25 \mathrm{~d}$.

Received on October 25, 2013

Priimta 2013 m. gruodžio 9 d.

Accepted on December 9, 2013
Corresponding author Gediminas Tankevičius

Lithuanian University of Health Sciences

Eivenių str. 2, LT-50009 Kaunas

Tel +37067044340

E-mailgedastank@yahoo.com 